\title{
Peace, love and lab work
}

\author{
Ann Finkbeiner delves into a collection reappraising the hippy tech-heads, \\ agronomic groovers and far-out ecodesigners of the 'long 1970s'.
}

$\mathrm{F}$ or a lively decade or so in the 1960 s and 1970s, the younger generation in the United States looked at its elders - with their unwinnable wars, florid military-industrial complex, intransigent racism and contaminated brownfields and was outraged. In particular, young people rejected what they saw as the foundations of many establishment ills: the weapons and toxic chemicals spawned by science and technology. That is the standard history, say historians of science David Kaiser and Patrick McCray - and it's not quite right.

In their edited volume Groovy Science, Kaiser (author of How the Hippies Saved Physics (W. W. Norton, 2011); see H. Gusterson Nature 476, 278-279; 2011) and McCray show that in the "long 1970s", the young, in creating a counterculture, didn't so much reject science as recreate it. Each essay is a case history on how the hippies repurposed science and made it cool.

What they rejected was the work of defence contractors, big government or corporate labs, which they deemed hierarchical, inflexible and bound to special interests. By contrast, 'groovy' science was (as hinted at by the word's origins in 1930s jazz) playful and improvisational, small-scale and done in the name of peace by "world-thinkers, dropouts from specialization". Their research ranged from the practical (light, strong surfboards) to the visionary (space travel). Because some were drug-addled, it also encompassed the harebrained (communication with dolphins, the fervent wish of physician John Lilly). Some of it is now thoroughly mainstream.

A number of these hippies were conventionally trained scientists with doctorates. Psychologist Abraham Maslow looked beyond the behaviourism - the idea that humans are blank slates who react to stimuli - advocated by psychologist B. F. Skinner and others. Maslow's alternative was a humanistic 'hierarchy of needs', the fulfilment of which would lead to happiness, selfactualization, and ultimately a better society. He became a patron of the Esalen Institute in Big Sur, California, a centre for workshops, encounter groups - forums that encouraged face-to-face communication and confrontation - and yoga classes, all aimed at training people to realize their potentials. His innovative approach, focusing on good mental health rather than pathological symptoms,

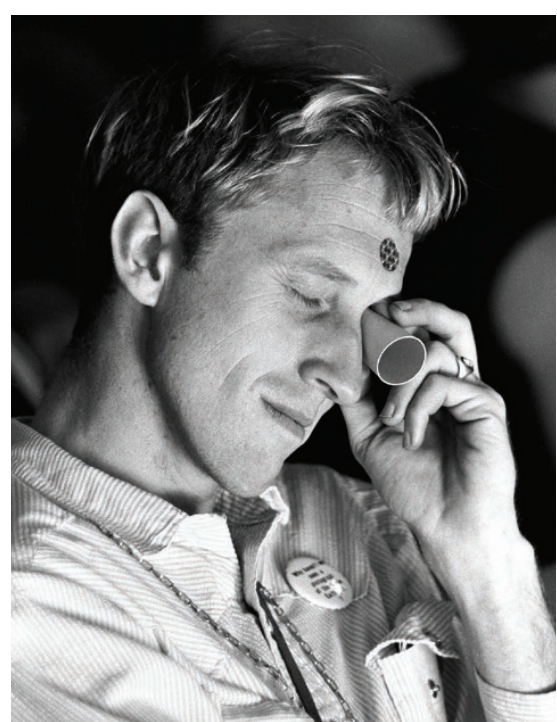

Writer Stewart Brand in 1966.

persists in 'positive psychology'.

John Todd, a biologist at San Diego State University in California, worried that industrial agriculture was creating dangerously limited monoculture. He organized a network of like-minded professionals, the New Alchemists, who encouraged agriculturally self-sufficient communities and built enclosed ecosystems, or 'bioshelters', such as the Ark on Canada's Prince Edward Island. Similar principles and technologies are now used by ecodesigners in creating green buildings that incorporate renewable materials and have sustainable energy demands.

Countercultural researchers jump-started interest in midwifery and home births; they also learned to produce their own cheese, making goat's cheese "no longer weird" in the United States. The grooviest of them all were arguably the bricoleurs, engineers in garages, who used "whatever comes to hand". As groundbreaking publisher Stewart Brand wrote in the Whole Earth Catalog (part encyclopaedia and part

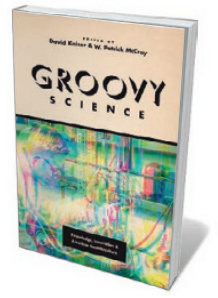

Groovy Science: Knowledge, Innovation, and American Counterculture EDITED BY DAVID KAISER AND W. PATRICK MCCRAY University of Chicago Press: 2016. how-to manual, often cited as anticipating the Internet), these were doers "with a functional grimy grasp on the world". Welder and designer Steve Baer and his friends experimented with passive solar collectors, and geodesic domes partly crafted from junked cars, in Colorado commune Drop City. He adapted the ideas for his New Mexico-based company Zomeworks. James Baldwin, a jack-of-all-trades, built a truck with fold-out sides that served as a travelling workshop and classroom for ecodesign technologies such as solar panels. Baldwin's toolkit was used to construct sustainable buildings, including the Farallones Institute in Occidental, California, established by architect Sim Van der Ryn to teach ecological design. As with the New Alchemists, this stream flowed into contemporary ecodesign.

Most noticeable about these science freaks was their cheery willingness to share whatever they knew or learned through manuals, periodicals and books, many of them bestsellers. Publications such as the magazine The Great Speckled Bird spread the ecodesign gospel. Science and science-fiction magazine Omni, influenced by psychologist and avid user of hallucinogenic drugs Timothy Leary, popularized his ideas of space migration and transhumanism - transcending human limitations. The Whole Earth Catalog famously offered tools for developing "person power" - everything from hammers to guides for building a pipe organ and books on population control. "We are as gods," Brand wrote, "and might as well get good at it."

For the academic historian, Groovy Science establishes the "deep mark on American culture" made by the countercultural innovators. For the non-historian, the book reads as if it were infected by the hippies' democratic intent: no jargon, few convoluted sentences, clear arguments and a sense of delight. Because of "acid-spooked scientists, stoned tinkerers, and many of the other straight-up hippies and freaks," write historians Beth Bailey and David Farber in the afterword, "a substantial subset of Americans came to rethink how they eat, how they communicate, how they stay healthy, how they design and build, and how they have fun." -

Ann Finkbeiner is a science writer in Baltimore, Maryland. e-mail:anniekf@gmail.com 